\title{
AGROECOLOGIA E CAMPESINATO: UMA NOVA LÓGICA PARA A AGRICULTURA DO FUTURO ${ }^{1}$
}

AGROECOLOGIA Y CAMPESINATO:

UNA NUEVA LÓGICA PARA LA AGRICULTURA DEL FUTURO

\section{AGROECOLOGY AND PEASANTRY:}

\author{
A NEW LOGIC FOR THE AGRICULTURE OF THE FUTURE
}

\section{Valeria de Marcos - DG FFLCH USP \\ Email: demarcos.vale@usp.br}

\begin{abstract}
Resumo: A fase atual de desenvolvimento capitalista tem buscado impor na agricultura um modelo de agricultura tecnificada, com a presença cada vez menor de trabalhadores no campo. Após o incentivo à expansão do cultivo de grãos transgênicos, outro caminho que tem sido aberto é aquele dos biocombustíveis - na verdade agrocombustíveis -, vendidos pela mídia como culturas "ecologicamente corretas". Trata-se de mais uma investida do agronegócio para tentar driblar os efeitos da crise pela qual tem passado, e da reapresentação dos monocultivos em grandes extensões, como é o caso da cana-deaçúcar para a produção do álcool combustível, cada vez em maior expansão no campo brasileiro, em especial naquele paulista. Os camponeses, porém, não têm aceitado essas imposições e têm buscado uma alternativa para o próprio futuro, e, com ele, também o nosso. É nesse quadro que a agroecologia tem ganhado cada vez mais espaço e, juntamente com ela, a discussão sobre a retomada da dimensão local do desenvolvimento, de um desenvolvimento que, além de local, seja capaz de autossustentar-se. O presente trabalho tratará dessa discussão a partir de exemplos bem sucedidos de produção e comercialização de produtos agroecológicos que têm proporcionado a camponeses no estado da Paraíba, do Alto Sertão à Zona da Mata, a conquista da liberdade e da autonomia camponesa através da reforma agrária.
\end{abstract}

Palavras-chave: agroecologia; feira agroecológica; mandala; assentamento rural; camponês.

\footnotetext{
${ }^{1}$ Os resultados deste trabalho fazem parte da pesquisa Agricultura para o futuro: práticas alternativas de agricultura camponesa na ótica do desenvolvimento local auto-sustentável, sob minha coordenação. Trabalho originalmente apresentado na Comunicação Coordenada Estratégias de reprodução e resistência camponesa: desafios e perspectivas, realizada no III Simpósio Internacional de Geografia Agrária/IV Simpósio Nacional de Geografia Agrária/Jornada Orlando Valverde, 2007, Londrina-PR. Trabalho publicado, com pequenas diferenças, nos Anais do III Simpósio Internacional de Geografia Agrária/IV Simpósio Nacional de Geografia Agrária/Jornada Orlando Valverde. Londrina: SINGA, 2007. p. 1-29.
} 
Resumen: La fase actual del desarrollo capitalista ha buscado imponer en la agricultura un modelo tecnificado con la presencia cada vez menor de trabajadores en el campo. A partir del incentivo que se promocionó con la expansión del cultivo de granos transgénicos, otro camino que ha sido abierto es el de los biocombustibles (o, mejor dicho, de agrocombustibles) vendidos por los medios de comunicación como culturas ecológicamente correctas. Sin embargo, se trata más bien de una embestida del agronegocio para intentar regatear los efectos de la crisis por la cual ha pasado y de la reaparición de los monocultivos en grandes extensiones, como el caso de la caña de azúcar para la producción del alcohol como combustible, cada vez más en crecimiento dentro del campo brasileño, sobre todo en el estado de São Paulo. No obstante, los campesinos no han aceptado estas imposiciones; por lo tanto, han buscado otra alternativa para su propio futuro y, con ello, también el nuestro. Es en este marco que la agroecología ha ganado cada vez más espacio y, asimismo con ésta, la discusión relacionada a la dimensión local del desarrollo que, además de local, sea capaz de autosustentarse. El presente trabajo tratará esta discusión a partir de ejemplos exitosos de producción y comercialización de productos agroecológicos que han proporcionado a campesinos del estado de Paraíba, del Alto Sertao a la Zona de Mata, la conquista de la libertad y la autonomía campesinas a través de la reforma agraria.

Palabras clave: agroecología, feria agroecológica, mandala, asentamiento rural, campesino

\begin{abstract}
The current stage of the capitalistic development has tried to impose in agriculture a model of technical agriculture, with a minor presence of workers in the countryside. After the incentive to the expansion of the cultivation of transgenic grains, another way that has been tried is the biofuels - actually agrofuels - showed by the media as "ecologically correct cultures". It is another attempt of the agribusiness trying to dribble the effects of the crisis through which it has been passing, and of the representation of the monoculturalism in great extensions, as it is the case of the sugar cane for the production of alcohol, in high expansion in the Brazilian countryside, specially in the state of São Paulo. The peasants, however, have not accepted these impositions and have looked for another alternative for their own future, and at the same time, for ours as well. It is in this context that the agroecology has gained more and more space and, at the same time, the debate on the resuming of the local dimension of a development that, besides being local, is able to be self sustainable. The present work will deal with this debate coming from successful examples of production and commercialization of agroecological products which have meant the achievement of freedom and autonomy over the land through the land reform to the peasants of the state of Paraíba, from Alto Sertão to Zona da Mata.
\end{abstract}

Key-words: agroecology; agroecology fair; mandala; rural settlement; peasants. 


\section{INTRODUÇÃO}

Um dos pontos de maior discussão na atualidade tem sido a retomada da dimensão local do desenvolvimento. Mais ainda, de um desenvolvimento que, além de local, seja capaz de autossustentar-se. Tal processo concretiza-se através da aplicação dos três pilares do desenvolvimento local autossustentável elencados por Magnaghi (2000): 1. a satisfação das necessidades básicas da comunidade (basic needs); 2. a autodeterminação das comunidades envolvidas através da construção de um projeto de desenvolvimento endógeno e em sintonia com a capacidade de realização das comunidades envolvidas (self reliance) e 3. a realização de práticas que não apenas respeitem o ambiente como ainda promovam a sua valorização (ecodevelopment). A esses três pilares, soma-se um quarto, enfatizado por Quaini (2002): 4. a necessidade de recuperação e valorização dos saberes locais praticados pelas comunidades para melhor poder valorizar as suas potencialidades.

Nessa perspectiva, a realização da reforma agrária assume uma dimensão central. Ao restituir à terra a sua função social, a reforma agrária não apenas oferece aos camponeses a possibilidade de reinserção social como dinamiza a economia local, regional e nacional. Tal fato, porém, não tem ocorrido da mesma forma e com a mesma intensidade em todas as regiões do país. Muitas são as dificuldades enfrentadas, da repetição de modelos tradicionais de prática agrícola à falta de orientação e assistência técnicas adequadas; da falta de créditos para a produção às dificuldades de comercialização, apenas para citarmos algumas delas. Tais problemas têm colocado aos camponeses a necessidade de unir-se para buscar alternativas ao modelo tradicional de prática agrícola e de comercialização da produção, e é nesse sentido que a agroecologia tem se configurado cada vez mais como uma alternativa para a produção - e comercialização - camponesa nas áreas de assentamentos rurais. A agroecologia é entendida como uma nova abordagem da agricultura, uma base científica que integra diversos aspectos agronômicos, ecológicos e socioeconômicos para a produção de alimentos, capaz de realizar a crítica da agricultura convencional e orientar o correto redesenho e manejo dos agroecossistemas em busca da autossustentabilidade.

Na Paraíba, essa é uma alternativa que tem conquistado cada vez mais espaço, tanto na Zona da Mata quanto no Alto Sertão. Praticada através de formas alternativas, 
como a mandala, ou em canteiros tradicionais, por um número cada vez maior de famílias, a produção agroecológica tem conquistado cada vez mais espaço entre os camponeses assentados. $\mathrm{O}$ sucesso alcançado estimulou o surgimento de uma alternativa também para a comercialização da produção: as feiras agroecológicas. Dentre elas destacam-se a Feira Agroecológica do Campus I da UFPB, em João Pessoa - a primeira do estado -, e as Feiras Agroecológicas de Cajazeiras e de Aparecida, no Alto Sertão paraibano $^{2}$. Tais feiras têm se configurado, cada vez mais, numa alternativa que tem garantido a melhoria da qualidade de vida e da renda das famílias envolvidas com essa prática. Mas essa realidade não é exclusiva do Nordeste brasileiro. Em diferentes locais do Brasil e também da América Latina essa tem sido uma alternativa que tem alcançado cada vez mais espaço - e resultados - entre os camponeses, sobretudo no que se refere à mudança na perspectiva de relação com a terra, o ambiente e as pessoas. O presente trabalho tratará das características principais da produção agroecológica realizada tanto através da forma tradicional quanto através das mandalas, bem como da organização e funcionamento das feiras agroecológicas acima citadas. O objetivo é o de demonstrar ser a agroecologia uma alternativa cada vez mais viável para a produção camponesa nas áreas de reforma agrária na atualidade e para a agricultura em geral.

\section{DA REVOLUÇÃo Verde À AgROECOLOGIA}

A agricultura moderna tem sua origem ligada às descobertas realizadas no século XIX, sobretudo à idéia de que o aumento da produção e da produtividade agrícola seria diretamente proporcional à quantidade de substâncias químicas incorporadas ao solo, teorias que colocavam em cheque a teoria do húmus, segundo a qual as plantas obtinham o carbono a partir da matéria orgânica do solo. Muito embora mais tarde esta última teoria tenha sido reforçada, os efeitos das teorias "agroquímicas" já se faziam sentir nos setores agrícola e industrial, e um promissor mercado para os fertilizantes químicos já estava se desenhando. Com o avanço desse poderoso setor, também a técnica de rotação de culturas - que já havia substituído a antiga rotação de terras - e a integração entre atividade agrícola e produção animal - velha forma para refertilização natural do solo - vão aos poucos deixando de ser utilizadas, dando lugar a uma exploração cada vez mais intensiva da terra, através da repetição das mesmas

\footnotetext{
${ }^{2}$ Quando realizamos a pesquisa, também estava sujeita a estudo outra feira agroecológica, em Patos, também no sertão.
} 
culturas e da aplicação de quantidades cada vez maiores de fertilizantes e corretivos químicos.

A revolução verde, como ficou conhecido o pacote tecnológico que passou a ser imposto como garantia do fim da fome que assolava o mundo e, em especial, a Europa pós-Segunda Guerra Mundial, significou, na verdade, como ressalta Porto Gonçalves (2004, p. 212), um conjunto de transformações nas relações de poder por meio da tecnologia, transformações estas que procuravam deslocar a atenção do sentido social e político das lutas contra a fome e a miséria. Uma revolução verde para se contrapor ao risco de revolução vermelha que vinha da China. Desnecessário dizer que tal revolução foi incentivada pelos órgãos governamentais e financiada por importantes instituições financeiras do mundo capitalista, como o Banco Mundial, o Banco Interamericano de Desenvolvimento (BID), a United States Agency for Internacional Development (Usaid) e a Food and Agriculture Organization of the United Nations (FAO).

O resultado foi a ampla divulgação e uso - com o apoio das universidades que passavam a formar os agrônomos e técnicos agrícolas com essa perspectiva - de fertilizantes químicos, agrotóxicos, sementes híbridas e seu mais recente desdobramento, com a biotecnologia dos transgênicos (leia-se "sementes com venenos incorporados, risco certo à saúde humana e ao ambiente, mas ganho certo para as empresas que as produzem") e das técnicas de plantio direto, por trás da difusão da idéia de que a fome - que é um problema econômico, social e político - seria resolvida por meio de um desenvolvimento técnico e científico.

A receita foi seguida à risca pelos então chamados países subdesenvolvidos, mas a fome continuou existindo. Os efeitos da tecnologia se faziam sentir: aumento da produção, às custas de um aumento do consumo de fertilizantes químicos e da queda da produtividade/hectare e, principalmente, o aumento cada vez maior da desigualdade na produtividade entre os setores mais avançados da agricultura capitalista e aqueles mais débeis. Além disso, a melhoria nas condições de armazenamento, transportes e comunicações, permitindo o aumento da produtividade total, propiciou a incorporação de novas áreas para produção, fato que, além de elevar a concentração de terras, aumentou ainda mais a produção e, consequentemente, reduziu o preço do produto no mercado. 


\begin{abstract}
Assim, a diminuição da renda diferencial por localização obtida graças à expansão e melhoria da rede de transportes e comunicações, a diminuição da renda diferencial por fertilidade da terra em função do próprio modelo agrário/agrícola capital intensive e a expansão da área cultivada vêm contribuindo tanto para o aumento do volume de produção como para uma acentuada queda dos preços dos grãos e, ainda, para uma concentração de capital e diminuição do trabalho (PORTO GONÇALVES, 2004, p. 213).
\end{abstract}

A lógica industrial instala-se no campo, seja através da redução do preço dos alimentos, ocasionando uma diminuição no custo da cesta básica para o trabalhador que vive na cidade, permitindo-lhe assim o aumento do consumo de produtos industrializados, seja através da industrialização da agricultura, via introdução de produtos industrializados (insumos e maquinários) e, mais recentemente, via introdução do modo industrial de produzir no campo (OLIVEIRA, 2005, 2007). Os resultados dessas conquistas no campo latino-americano, em especial na fração camponesa desse campo, porém, foram bem outros: o desgaste do solo; o desaparecimento de culturas locais devido à homogeneização dos cultivos agrícolas e a consequente redução da biodiversidade; o aumento da produção de grãos - nos últimos anos através da expansão dos transgênicos - e a redução da renda devido à redução dos preços desses produtos no mercado internacional cada vez mais mundializado; a perda da soberania alimentar e a dependência cada vez maior dos camponeses que resistem no campo às grandes corporações multinacionais, via uso de sementes transgênicas estéreis das quais empresas como Monsanto, Syngenta, Bayer, Dupont e Novartis são apenas alguns exemplos de uma lista que não para de crescer. Por último, mas não menos importante, há o aumento da concentração de terras através da expansão do agronegócio pelo campo latino-americano, vendido pela mídia como sinônimo de "modernidade", mas reprodutor de uma lógica velha conhecida nossa, a dos monocultivos de commodities como a cana-de-açúcar, soja, trigo, milho, agora de cara nova: uma agricultura extremamente tecnificada, que acaba dando lugar a um campo sem trabalhadores, atualmente divulgada como "ecologicamente correta" com a transformação desses produtos em "combustível limpo". Do dia para noite, a busca de uma saída para a crise iminente diante da saturação de consumo e da queda dos preços desses produtos no mercado internacional transforma-se em "preocupação ambiental” e a certeza de lucro é mais uma vez garantida. 
É justamente dessa crise que emerge a busca por uma agricultura alternativa, uma saída ao padrão produtivo convencional. É nesse quadro que se inserem a permacultura, a agroecologia e a nova forma de pensar a produção agrícola e a relação com a terra que elas comportam. O objetivo é aquele de conseguir uma agricultura que permita a produção estável e eficiente de alimentos, a segurança e soberania alimentar, a preservação da cultura local e da pequena unidade de produção e o uso de práticas agroecológicas ou tradicionais de manejo (ALTIERI; NICHOLLS, 2000, p. 21). Dessa forma, chegar-se-ia a uma agricultura sustentável, capaz de garantir a conservação dos recursos renováveis, a adaptação dos cultivos e a manutenção de níveis moderados, mas sustentáveis, de produtividade. O grau de eficiência dessa agricultura seria, segundo Altieri e Nicholls (2000, p. 24-7) verificado através dos seguintes critérios:

1. Sustentabilidade: habilidade de um agroecossistema de manter a produção através do tempo, diante de repetidas restrições ecológicas e pressões socioeconômicas;

2. Equidade: grau de uniformidade com que são distribuídos os produtos do agroecossistema entre os produtores e consumidores locais;

3. Estabilidade: constância de produção sob um grupo de condições ambientais, econômicas e de manejo;

4. Produtividade: quantidade de produção por unidade de superfície, trabalho e insumos utilizados.

As formas de colocar esses objetivos em prática variam, todas elas buscando um novo equilíbrio agroecossistêmico. Um exemplo disso é o que ocorre com a permacultura, termo criado por Mollison e Holmgren para indicar "um sistema integrado e em evolução, constituído de plantas perenes ou que se autoperpetuam, e por espécies animais úteis ao homem. Trata-se, substancialmente, de um ecossistema agrícola completo" (MOLLISON; HOLMGREN, 1992, p. 9, tradução nossa), de uma síntese entre práticas agrícolas tradicionais e idéias inovadoras, entre conhecimento secular e descobertas da ciência moderna, proporcionando o desenvolvimento integrado da propriedade rural de forma viável e segura. 
Uma permacultura eficiente, por exemplo, captura, armazena e controla a água da chuva, acumula gradativamente reservas alimentares e produz novos microclimas, aumentando as espécies úteis e melhorando as condições climáticas mais extremas. (PUCCI apud MOLLISON; HOLMGREN, 1992, p. 5, tradução nossa).

Trata-se, pois, de maximizar as combinações entre as diversas funções e, com isso, criar a perspectiva de constituição de fileiras econômicas que possibilitem o fechamento do ciclo ecológico. “O projeto permacultural envolve o planejamento, a implantação e a manutenção conscientes de ecossistemas produtivos que tenham a diversidade, a estabilidade e a resistência dos ecossistemas naturais."

Nessa perspectiva, dois exemplos de práticas agrícolas alternativas e autossustentáveis merecem ser destacados: a agricultura natural proposta por Fukuoka no Japão e a agricultura sinérgica, adaptação da proposta de Fukuoka à realidade européia, iniciada por Emilia Hazelip na Espanha e continuada na Itália por Antonio De Falco, Fortunato Fabbricini e seus seguidores. Trata-se de uma forma inovadora de praticar a agricultura, baseada na autofertilização do solo. O princípio norteador é aquele de deixar a natureza agir por si própria. Como diria Fukuoka, a sua é uma agricultura "do não fazer”, baseada em cinco princípios norteadores:

1. Nenhum tipo de trabalho, nem aragem, nem tombamento do terreno: a terra é trabalhada pela penetração das raízes das plantas e pelas atividades dos microorganismos, pequenos animais e minhocas;

2. Nenhum adubo químico nem composto preparado: deixado a si próprio, o solo conserva naturalmente sua própria fertilidade, de acordo com o ciclo da vida vegetal e animal;

3. Nenhuma deserbagem, nem com enxada, nem com deserbantes: as ervas ditas "daninhas" possuem o seu papel na construção da fertilidade natural do solo e na manutenção do equilíbrio da comunidade biológica;

4. Nenhuma dependência de produtos químicos: as doenças e desequilíbrios tiveram início com as práticas não naturais na agricultura, como a aragem e a adubação. Insetos nocivos e patogênicos sempre existiram na natureza, mas se os

\footnotetext{
${ }^{3}$ Informação obtida no site da Rede Brasileira de Permacultura, www.permacultura.org.br no link "Saiba mais sobre a permacultura". Última consulta realizada em 05. nov. 2005.
} 
princípios da agricultura natural são respeitados, eles nunca chegam a causar danos irreversíveis;

5. Nenhuma podagem: o respeito à forma natural das árvores permite o máximo crescimento e a máxima exposição à luz solar, a melhor distribuição e fornecimento de nutrientes e, portanto, o máximo rendimento.

No caso da agricultura sinérgica, busca-se respeitar os princípios da agricultura natural após a instalação das hortas. Trata-se, portanto, de uma "agricultura domesticada", como dizem os seus idealizadores. Se a área a ser cultivada tiver sido largamente utilizada, é necessário avaliar o seu grau de desgaste para identificar a melhor forma de agir. Nos casos de grande desgaste, recomenda-se o plantio de leguminosas "em campo aberto", sem a preparação tradicional. Basta “jogálas" na terra e cobrir com uma cobertura de palha ou outro material biodegradável, deixando-as germinar por conta própria. Em terrenos muito desgastados, recomenda-se a repetição dessa prática por dois anos antes de passar ao cultivo sinérgico ${ }^{4}$. Uma vez preparado o terreno, deve-se escolher se cultivá-lo com cereais "em campo aberto" ou preparar as hortas. Adotando a primeira opção, basta repetir a operação anterior. No caso da segunda, é necessário preparar os canteiros.

Para a preparação da horta, o primeiro passo é a escolha do local. Como nesse tipo de horta não importa o seu tamanho, mas a sua diversidade, recomenda-se que ela seja preparada próxima à casa para facilitar o trabalho. O solo é inicialmente preparado através da construção dos canteiros, organizados de modo a permitir o plantio e colheita sem que para isso seja necessário pisá-los ou revirá-los, o que geralmente corresponde a uma forma de espiral, que permite uma melhor circulação para o manuseio dos canteiros. Em seguida passa-se à construção dos canteiros com $120 \mathrm{~cm}$ de largura e 50 $\mathrm{cm}$ de altura, bem como à instalação de um sistema de irrigação e à escolha dos produtos a serem semeados. Concluída a fase preparatória, os produtos são semeados, colocando-se em um mesmo canteiro o maior número possível de espécies. Em seguida as sementes ou mudas são cobertas com palha ou outra cobertura biodegradável. Nas bordas, aconselha-se o plantio de plantas aromáticas e flores que servem para atrair

\footnotetext{
${ }^{4}$ Para o segundo ano, as plantas são deixadas no próprio terreno e o plantio deve ser repetido como da primeira vez: as sementes são lançadas no terreno que vem novamente coberto por palha ou outro tipo de cobertura biodegradável (podem ser usados pedaços de papelão).
} 
insetos benéficos, possuem função antibactérica e afastam os nematóides e outros parasitas. Nas laterais, aconselha-se o plantio de plantas selvagens e, na parte superior, os gêneros que serão cultivados misturados entre si. Dali em diante os produtos serão cultivados sem o uso de adubo, fertilizante, pesticidas, e sem que seja realizada a movimentação do terreno, baseando-se no princípio da autofertilização do solo.

Outro exemplo de prática agrícola que segue os mesmos princípios da permacultura é o da agroecologia, entendida enquanto uma nova abordagem da agricultura que integra diversos aspectos agronômicos, ecológicos e socioeconômicos, na avaliação dos efeitos das técnicas agrícolas sobre a produção de alimentos e na sociedade como um todo. Trata-se do resultado de um sistema de produção agrícola que busca manejar, de forma equilibrada, o solo e demais recursos naturais (água, plantas, animais, insetos etc.), conservando-os em longo prazo e mantendo a harmonia desses elementos entre si e com os seres humanos. Desse modo, para se obter um alimento verdadeiramente orgânico, é necessário administrar conhecimentos de diversas ciências para que, através de um trabalho harmonizado com a natureza, se possa ofertar ao consumidor alimentos que promovam não apenas a saúde deste último, mas também do planeta como um todo.

No caso da agroecologia, um dos pontos que merecem maior atenção é o uso das sementes. Para que se possam cultivar produtos verdadeiramente agroecológicos, o ideal seria dar preferência ao uso das sementes crioulas, obtidas através do método de seleção massal, que consiste em coletar as sementes que demonstraram ao longo do tempo uma ou mais características desejáveis, como potencial de alto rendimento ou resistência a doenças, para plantá-las na safra seguinte. As sementes crioulas são adaptadas às condições locais e possuem, internamente, maior variabilidade genética quando comparadas às variedades obtidas por outros métodos. Além disso, elas atendem a um dos princípios básicos da agroecologia, o de desenvolver plantas adaptadas às condições locais da propriedade, capazes de tolerar variações ambientais e ataques de organismos prejudiciais. Outro aspecto importante consiste na maior autonomia do agricultor, que pode coletar as sementes dessas variedades e replantá-las no ano seguinte, adquirindo maior independência do mercado de insumos e gerando um material que, com toda sua variabilidade genética, se torna cada vez mais vigoroso e 
adaptado ao seu tipo de solo e clima ${ }^{5}$. Exemplo dessa prática é a experiência dos Bancos de Sementes na Paraíba, denominados Sementes da Paixão, muitos deles localizados no Alto Sertão paraibano.

No entanto, o uso dessas sementes ainda está longe de acontecer em larga escala. A maior parte daqueles que se dedicam à agroecologia adquirem suas sementes a partir de plantas cultivadas em manejo convencional, e que continuam recebendo fertilizantes altamente solúveis e agrotóxicos para a sua produção. Além disso, grande parte dessas sementes são híbridos ou variedades obtidas por outros métodos de melhoramento que não a seleção massal, fato que proporciona pouca variabilidade genética e maior suscetibilidade ao ataque de insetos prejudiciais e doenças, exigindo mais trabalho para equilibrar a saúde dessas plantas ${ }^{6}$.

Outros aspectos que fazem parte das práticas culturais na agroecologia são: o uso de matéria orgânica como fertilizante; a produção artesanal de biofertilizantes; a semeadura escalonada e o estudo do espaçamento no plantio para a obtenção do máximo rendimento possível; o cuidado com a água utilizada, além das práticas culturais em respeito ao ambiente; a valorização dos saberes e práticas locais, principalmente no que se refere ao conhecimento dos camponeses sobre o tipo de solo, plantas e processos ecológicos; e o uso de tecnologias simples, de fácil uso e difusão. Tudo isso pensado e praticado a partir da realidade da comunidade camponesa, de seus conhecimentos e recursos disponíveis e, sobretudo, de suas aspirações e anseios. Tratase de uma forma de pensar um desenvolvimento rural endógeno. Todas essas características fazem da agroecologia, mais que uma alternativa, uma necessidade para a agricultura do futuro.

\footnotetext{
5 Maiores informações podem ser consultadas em http://www.planetaorganico.com.br/sement2.htm Última consulta realizada em 05. nov. 2005.

6 Os híbridos são, na maioria das vezes, o resultado de um longo processo seletivo no qual se privilegiam aspectos como a otimização do rendimento, gosto e aparência atraentes, uniformidade genética, resposta rápida à aplicação de água e fertilizantes, facilidade de colheita, processamento e vida mais longa na prateleira dos pontos de venda, todos em total respeito à lógica capitalista do maior ganho possível. O resultado são plantas com uma menor capacidade de resistir a estresses, ameaças ou fatores limitantes do ambiente. Outro problema apresentado pelos híbridos é que eles, quando replantados, não originam produtos com a mesma "qualidade" original. Em alguns casos são inclusive estéreis, fato que obriga a aquisição de novas sementes, gerando muita dificuldade, sobretudo aos pequenos camponeses. Maiores informações podem ser consultadas em http://www.jardinseplantas.hpg.ig.com.br/home/sementes 000.htm. Última consulta em 05. nov. 2005.
} 


\section{Desenvolvimento local autossustentável, Agroecologia e Reforma AGRÁRIA: UM CAMINHO POSSÍVEL}

O desenvolvimento do modo capitalista de produção no campo brasileiro tem se dado de modo desigual e contraditório: ao mesmo tempo em que o capital se expande por alguns setores da agricultura estabelecendo relações capitalistas de produção, contraditoriamente, cria e recria relações não-capitalistas de produção no campo, entre elas as relações camponesas de produção (OLIVEIRA, 1987, 1992, 2004). Assim, contrariamente ao defendido pelas teses clássicas, o avanço do capitalismo no campo brasileiro, ao invés de promover o completo desaparecimento do campesinato, abre a possibilidade de sua (re)produção e (re)criação, a qual tem se dado, em muitos casos, através da busca e criação de caminhos que garantam sua autonomia e liberdade, e não através da total subordinação ou dependência à lógica capitalista que o cria e recria, como tem sido afirmado por teóricos como Abramovay (1990).

Um desses caminhos tem sido o retorno à terra, através da luta pela reforma agrária, contando para isso com o apoio dos movimentos sociais organizados no campo, como o MST, a CPT - que na Paraíba pode ser caracterizada como um verdadeiro movimento social - entre outros. Nos assentamentos rurais, loci privilegiados para a busca da concretização do desenvolvimento local autossustentável, os camponeses têm enfrentado uma luta ainda maior: aquela pela reprodução. Tais dificuldades, porém, têm servido de estímulo à busca de caminhos que garantam a reprodução sem sujeição. E é justamente onde as dificuldades são maiores que nascem as mais interessantes experiências de reprodução camponesa calcadas na solidariedade, na liberdade, na autonomia e na retomada da (u)topia camponesa da coletividade.

É nesse quadro que se inserem os assentamentos Acauã (Aparecida-PB), Frei Damião e Santo Antonio, (Cajazeiras-PB), no Alto Sertão paraibano, e os assentamentos Dona Helena (Cruz do Espírito Santo-PB), Padre Gino, Rainha dos Anjos e João Pedro Teixeira (Sapé-PB) e o acampamento Ponta de Gramame (Valentina-PB), todos na Zona da Mata, e palcos das mais interessantes experiências de reprodução sem sujeição. Nos assentamentos do Alto Sertão encontramos a autogestão de Associação, no Assentamento Acauã; a criação dos bancos de sementes da paixão; a socialização camponesa através do trabalho das crianças nos viveiros de mudas; os 
cultivos agroecológicos; as feiras agroecológicas; as farmácias vivas; a apicultura; a discussão sobre o uso racional da água, sobre educação, saúde e alimentação dos camponeses assentados. Nos assentamentos da Zona da Mata, há a primeira experiência de produção e comercialização de produtos agroecológicos, a qual serviu de exemplo e estímulo para outras tantas que foram surgindo em diversos pontos do estado.

Em ambos os casos, a CPT tem desempenhado um papel fundamental no apoio e incentivo aos camponeses envolvidos na realização dessas novas iniciativas. No Alto Sertão, o diferencial foi o trabalho conjunto realizado pela CPT-Sertão e pela Articulação do Semi-Árido (ASA), que organizaram as experiências através de redes cuja ação pode ser observada tanto no interior da própria atividade quanto na ligação entre elas ${ }^{7}$. O objetivo é a busca de experiências simples e de resultado, autossustentáveis, que permitam o respeito ao ambiente e a convivência com a seca em condições mais dignas. A organização dessas redes é uma clara demonstração de que o coletivo não só faz parte da lógica da recriação camponesa, como é o caminho mais curto para a construção de um território camponês de liberdade, autonomia e solidariedade. Na Zona da Mata, a CPT também teve um papel decisivo, incentivando a discussão entre os camponeses sobre os problemas enfrentados pela comercialização da produção e a busca de caminhos alternativos para minimizar - quando não neutralizar - a ação dos intermediários nos assentamentos. Importante parceira foi a Cáritas, que apoiou o processo de discussão, financiou uma visita às áreas de produção agroecológicas no sul do país e emprestou o dinheiro necessário para o início da atividade. Para o presente trabalho, concentraremos nossa atenção em dois dos exemplos acima citados: de um lado, a produção agroecológica através das mandalas no Alto Sertão, o resultado da experiência e o ensinamento deixado e, de outro, o longo caminho que levou à realização da feira agroecológica do Campus I da UFPB, os resultados alcançados e a difusão da experiência para outras áreas do estado.

\footnotetext{
${ }^{7}$ As redes através das quais o trabalho se organiza são as seguintes: Rede Abelha, Rede de Cultivos Agroecológicos, Rede Sementes, Rede Educação, Rede Saúde e Alimentação e Rede Água.
} 


\section{Assentamento ACauÃ, Alto Sertão paraibano: das mandalas À ConsCiênCia AGROECOLÓGICA}

A idéia de implantação das mandalas no Assentamento Acauã foi de Willy Pessoa, técnico do Sebrae-PB no início dos anos 2000 que, em visita ao assentamento, resolveu pensar com os camponeses soluções para as dificuldades no processo de produção por eles vivenciadas. No assentamento Acauã, um dos maiores problemas, além da falta d'água, é a distância das parcelas em relação à agrovila. Alguns camponeses têm que caminhar mais de cinco horas para se deslocar de um ponto a outro. Além disso, a falta de acesso à água na parcela limita muito as possibilidades de exploração econômica das mesmas. A idéia do técnico era instalar uma horta no quintal da casa dos camponeses e diversificar a produção, de modo a melhorar a alimentação das famílias e propiciar uma renda extra. Sua proposta era a construção de um tanque, de onde sairiam mangueiras que levariam a água, com o auxílio de uma bomba de baixa potência, aos canteiros que deveriam ser instalados próximos a ele. Para facilitar, pensou em um tanque central e circular, com canteiros a ele concêntricos.

Após muitas reuniões instalou-se a primeira mandala na sede da associação, em 2001, a qual serviu como recurso didático para a construção das demais. Aos poucos mais famílias se interessaram pela experiência e passaram a construí-la artesanalmente nos quintais de casa, adaptando-a ao espaço disponível e às condições do terreno. Diante do aumento de interesse por parte dos camponeses, realizaram-se dois projetos, um financiado pelo Sebrae e outro pelo Incra, ambos a fundo perdido. Assim, em menos de um ano da construção da primeira mandala, sessenta e três novas mandalas foram construídas nos quintais de sessenta e três famílias, correspondendo a quase $50 \%$ do número das famílias assentadas em Acauã. Segundo depoimento dos camponeses assentados, entre os motivos que impediram uma maior expansão das mandalas estão as condições geológicas do terreno dos quintais das casas - os solos são bastante rasos, o que propicia o aparecimento dos afloramentos rochosos cristalinos, impedindo consequentemente a escavação do tanque, que se faz imprescindível para a irrigação das lavouras - e a falta de confiança na viabilidade de tal prática.

O sucesso da experiência fez com que ela se difundisse e levou Acauã para as manchetes de revistas e programas de televisão especializados, transformando-o em 
uma referência no Alto Sertão. Muitas prefeituras locais passaram a visitar o assentamento e a divulgar a experiências entre as suas comunidades camponesas. $\mathrm{O}$ técnico, percebendo que poderia lucrar com isso, saiu do Sebrae, abriu a Agência Mandalla e patenteou a mandala aprimorada pelos camponeses de Acauã que, de fato, foram aqueles que lhe deram forma ${ }^{8}$. A partir de então, passou a divulgá-la por todo o país e a ganhar dinheiro com sua instalação.

A mandala atual tem uma forma circular, com um tanque central de onde partem as mangueiras que irrigarão os nove canteiros dispostos em círculos concêntricos, "inspirados" no sistema solar, com o sol no centro e os planetas ao redor ${ }^{9}$. O processo de construção inicia-se com a visita dos técnicos da Agência para vistoria do local, avaliação das condições existentes e individuação do que poderá ser aproveitado e do que deverá ser adquirido. A infraestrutura já disponível na casa não entra no cálculo e muitos dos custos da mandala acabam ficando por conta do camponês que a implanta.

A área mínima exigida para implantação da mandala é de um quarto de hectare. Para a sua construção, deve-se primeiro escolher um local próximo à casa. Depois, com o auxílio de um bastão de madeira, marca-se o centro e, com um cordão de três metros de comprimento com outro bastão de madeira amarrado na ponta, marca-se a circunferência correspondente ao tamanho do tanque. O passo seguinte é a construção do tanque que armazenará a água para a irrigação.

Deve-se começar a cavar pelo meio. $\mathrm{O}$ tanque deve ter $1,80 \mathrm{~m}$ de profundidade e o formato de um funil. À medida que o tanque é cavado, deve-se ir aplainando a superfície. Em seguida é necessário rebocar as paredes e as bordas do tanque com cimento, areia e tijolo. Nesse tanque (foto 1) serão criados peixes, marrecos e patos. $\mathrm{O}$ intuito é criar um ambiente através do qual os peixes e os patos enriqueçam a água que será depois bombeada para os canteiros. Deve-se deixar também $2 \mathrm{~m}$ entre as margens

\footnotetext{
${ }^{8}$ Segundo depoimento de integrantes do assentamento, W. Pessoa tinha a idéia, mas não a prática. Muitas vezes, inclusive, insistia em procedimentos que os camponeses, conhecedores das qualidades do solo de Acauã, sabiam de antemão que não dariam certo. Vários deles chegaram a relatar que o técnico fazia de um jeito na mandala modelo, mas que ele - camponês - em casa fazia de outro, dava certo e aí o chamava para ver. Um dos exemplos foi a forma de impermeabilizar o tanque: a atual proposta de cimentá-lo foi decorrência do exemplo oferecido por um camponês de Acauã, após provar que a lona preta sugerida rasgava-se com facilidade. Foi assim que a mandala foi ganhando forma.

9 A palavra mandala tem a sua origem no sânscrito, significando "círculo". O formato redondo é encontrado na natureza e desperta uma idéia de infinito, de prolongamento.
} 
do tanque e os canteiros. A área é cercada com uma tela de arame, para evitar que os patos e os marrecos circulem entre os canteiros e estraguem as plantações. No interior desse recinto, encontra-se ainda o ninho para que os patos possam chocar os ovos, o tanque para a produção de biofertilizante e um aparato com mangueiras que levam a água para os canteiros através de uma bomba (foto 2).

A água do tanque é bombeada para irrigar a produção que o circunda através de mangueiras plásticas perfuradas manualmente com o auxílio de um prego e, no furo, são colocadas hastes de cotonetes, cabinhos de pirulitos (foto 3) ou plásticos de empalhar cadeira $^{10}$ (foto 4 ) como aspersores. Uma de suas pontas é presa ao furo, ao passo que a outra é vedada a fogo. O jato d'água sai de um corte feito na lateral do cotonete, e é capaz de alcançar um metro de distância ${ }^{11}$ em qualquer direção, bastando para tanto girar a haste oca. A distância indicada pela agência é de $1 \mathrm{~m}$ entre os furos, mas a prática mostrou a necessidade de diminuí-las ou aumentá-las, dependendo da quantidade de água que a cultura exige.

Cada círculo possui uma mangueira para irrigar e duas torneiras de passagem, cada uma das quais permite a passagem d'água para uma metade do círculo. O problema é que essa "engenhoca" molha apenas um lado do canteiro, devendo depois o camponês girá-la para irrigar o outro lado. No início, enquanto a mandala não está completa, basta uma bomba-sapo, que normalmente funciona bem para os três primeiros círculos. Quando, porém, os nove círculos são implantados, torna-se necessária uma bomba com potência maior.

\footnotetext{
${ }^{10}$ As hastes de cotonete permitem pouca vazão, sendo preferidos os plásticos de empalhar cadeira.

${ }^{11} \mathrm{O}$ alcance do jato d'água dependerá da potência da bomba. No caso da utilização de bombas simples, com baixa potência, como é o caso da bomba-sapo utilizada no Assentamento Dona Helena, tal alcance ocorre somente nos primeiros círculos. Naqueles mais distantes, a água sai praticamente por gotejamento, obrigando a família a estar por perto e, em alguns casos, a irrigar o canteiro com a própria mangueira ou com regador.
} 


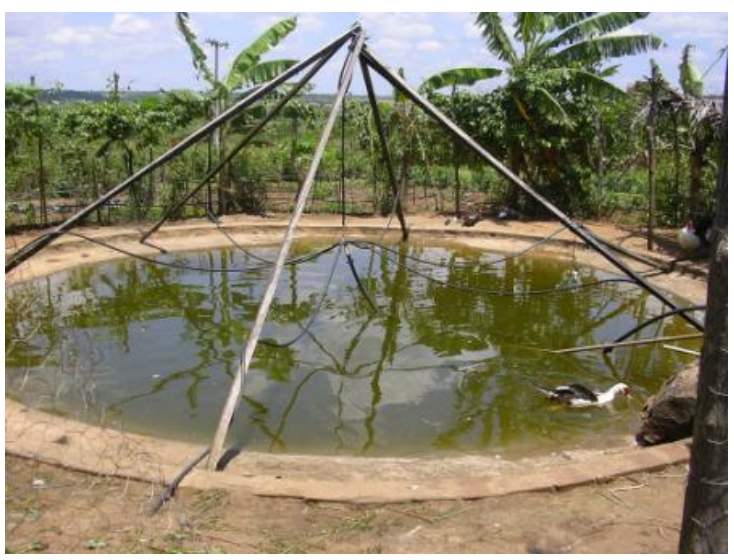

Foto 1 Tanque para irrigação. Mandala no assentamento Dona Helena, Cruz do Espírito Santo-PB. Foto: Valeria de Marcos. Out/2005.

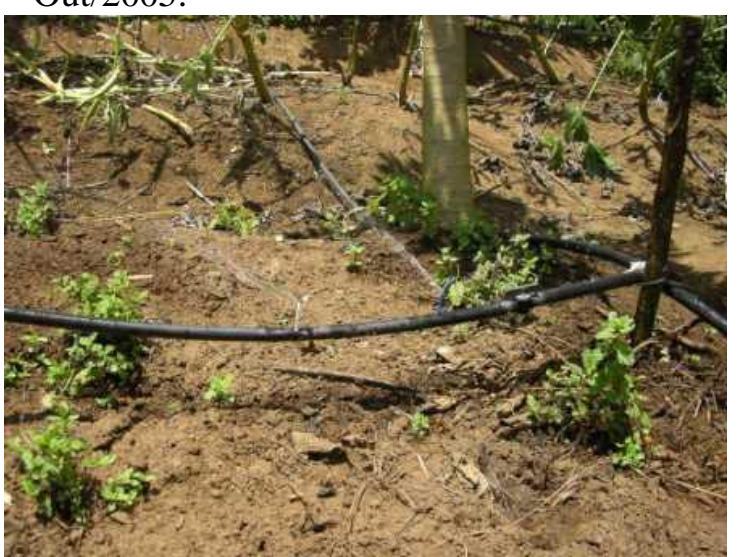

Foto 3 Irrigação com cotonete e pirulito. Mandala no assentamento Dona Helena, Cruz do Espírito Santo-PB. Foto: Valeria de Marcos. Out/2005.

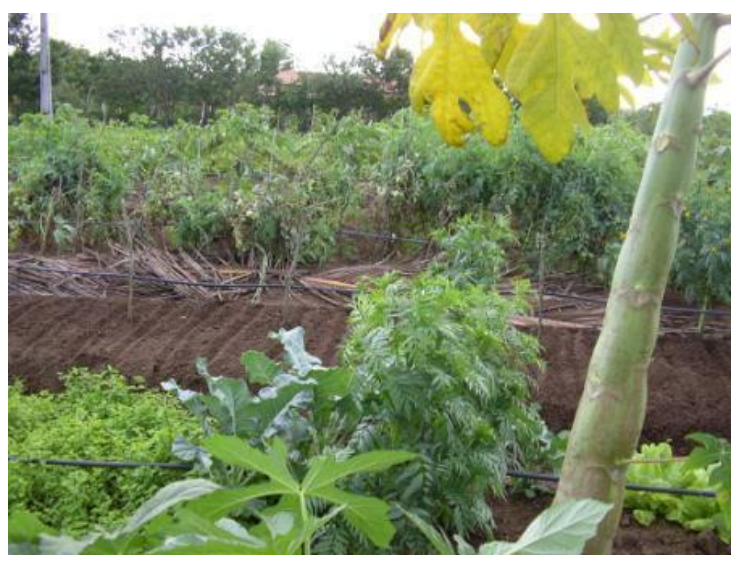

Foto 2 Mangueiras para irrigação nos canteiros. Mandala no assentamento Dona Helena, Cruz do Espírito Santo-PB. Foto: Valeria de Marcos. Out/2005.

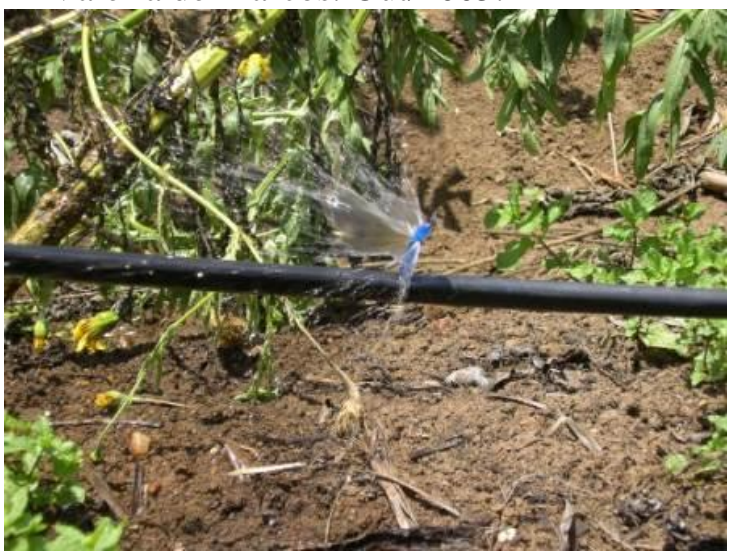

Foto 4 Irrigação com plástico para empalhar cadeira. Mandala no assentamento Dona Helena, Cruz do Espírito Santo-PB. Foto: Valeria de Marcos. Out/2005.

Ao redor do recinto fechado do tanque começa-se a construir os canteiros circulares. A largura do canteiro é de $1,20 \mathrm{~m}$, para permitir a colheita sem o pisoteamento dos canteiros. Segundo a orientação da agência, os três primeiros círculos correspondem ao que chamam "círculos da vida", e devem ser cultivados com hortaliças para o consumo da família. Os cinco círculos sucedentes (do quarto ao oitavo) devem ser cultivados com culturas comerciais. O nono círculo deve ser cultivado com "cerca viva", para proteger a mandala (fotos 5 e 6 ) de vento e também de polinização externa.

Contudo, muitas modificações são feitas nas mandalas instaladas. No primeiro círculo alguns camponeses plantam bananeiras, maracujá, plantas medicinais, bertalha e 
algumas hortaliças. Esse círculo tem também a função de quebrar o vento e proteger os patos no tanque. No segundo círculo também encontramos fruteiras (mamão), plantas medicinais e hortaliças. Do terceiro ao sétimo círculo normalmente encontram-se produtos que serão consumidos e comercializados. No nono círculo, ao invés da cerca viva, algumas famílias cultivavam macaxeira que, além de servir como cerca, pode também ser usada para a alimentação da família e para a comercialização. Entre as plantas cultivadas existem plantas medicinais e aromáticas, como hortelã e hortelã da folha grossa, cebolinha, manjericão, e flores, como cravo de defunto, entre outras, que têm a função de atrair insetos que podem comer as pragas ou de repelir as pragas ou insetos nocivos. $\mathrm{O}$ aspecto geral da mandala pode ser visto nas figuras 1 e 2 .

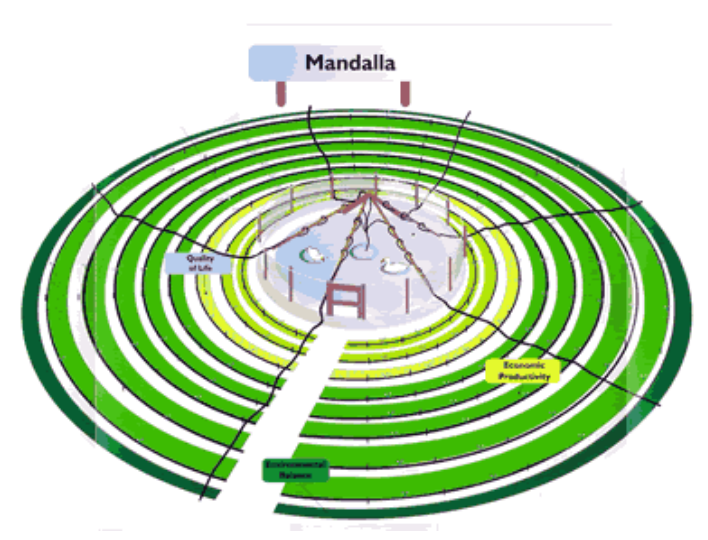

Figura 1 Mandala - desenho. In: http://www.agenciamandalla.org.br.

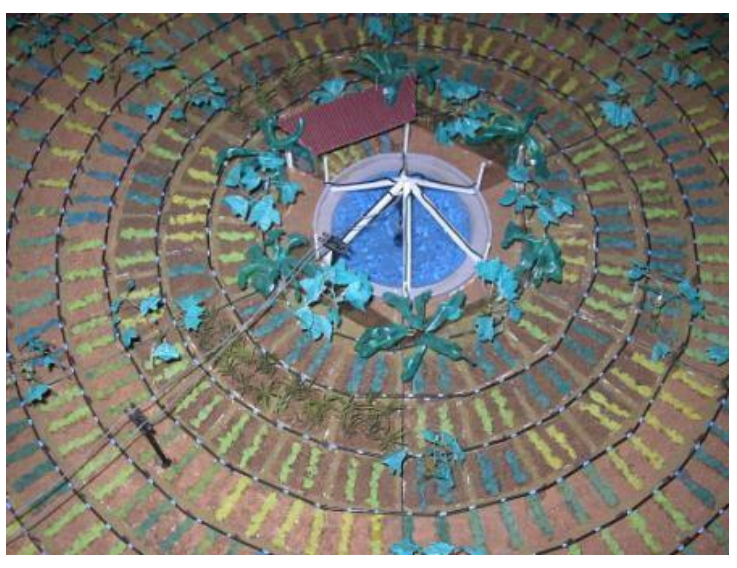

Figura 2 Mandala - maquete. Foto: Valeria de Marcos. Set/2004.

Para obter o melhor rendimento, também se altera o espaçamento entre as fileiras para facilitar a escarificação e assim manter o solo sempre areado. Como adubo, utilizam-se esterco, compostagem, cobertura morta e biofertilizante. O biofertilizante é fabricado de forma caseira, utilizando esterco bovino, cinza, matérias mortas (como folhas), leite, soro, açúcar, urina de gado, fumo, cal e água. Normalmente, deve-se esperar a fermentação por 30 dias, mas nos casos em que se possui apenas um tanque, costuma-se esperar apenas uma semana. Depois de fermentado, o biofertilizante é coado, colocado em uma bomba e pulverizado sobre as culturas uma ou duas vezes por semana. A idéia é aquela de que é melhor prevenir do que tratar. Assim, a pulverização periódica dos canteiros, o cultivo de plantas repelentes - cravo e cebolinha, por exemplo 
-, bem como a rotação das culturas pelos canteiros para evitar o enfraquecimento do solo, são práticas adotadas para enriquecer o solo e, ao mesmo tempo, prevenir o ataque de possíveis doenças. Todas essas práticas culturais estão em sintonia com os princípios da agroecologia.

Muito embora o princípio seja aquele de diversificar a produção, colocando vários cultivos em um mesmo canteiro (sem misturá-los, como acontece nas agriculturas natural e sinérgica), algumas famílias alegaram que tal prática torna um problema a quantidade de água a ser utilizada, já que algumas culturas pedem mais água do que as outras, sendo necessário escolher bem as culturas que compartilharão a metade do canteiro que será irrigada ao mesmo tempo. Outras adaptações referem-se à forma circular. Em Acauã, quando pedíamos para ver a mandala, os camponeses nos mostravam os tanques. Poucas foram as mandalas que seguiam o formato circular. Em geral, existia o tanque e os canteiros organizados de forma paralela ou perpendicular a ele, e até mesmo um tanque quadrado chegou a ser visto. Tais fatos são a prova de que os camponeses aproveitam dos ensinamentos técnicos aquilo que lhes serve e, com base nos seus saberes locais, adaptam e melhoram de acordo com as suas necessidades. E é isso que garantirá a sua autossustentabilidade.

Seguindo à risca ou adaptando-a às suas necessidades e possibilidades, o resultado da experiência foi a diversificação das culturas, garantindo a um só tempo melhorias na dieta alimentar das famílias e uma pequena produção excedente que passou a ser comercializada - inicialmente no interior do próprio assentamento ou com conhecidos em Aparecida. Não tardou, porém, para que os camponeses de Acauã, impulsionados pelo exemplo da Feira Agroecológica do Campus I da UFPB, decidissem iniciar a comercialização através da Feira Agroecológica de Aparecida, iniciada a partir da produção agroecológica de Acauã e dos assentamentos vizinhos que haviam aderido a essa nova forma de cultivo, boa parte deles de Cajazeiras. Do sucesso da experiência nasce outra feira agroecológica, a Feira Agroecológica de Cajazeiras, e Acauã passa a responsabilizar-se pela maioria do abastecimento da feira de Aparecida.

O sucesso da experiência, porém, não tardou a transformar-se em problema. Impulsionados pela possibilidade de diversificação da produção, de melhoria da alimentação e de ganhos extras, os camponeses de Acauã passaram a diversificar 
sempre mais e a introduzir culturas que necessitavam de um grande consumo de água. Some-se a isso a instalação do mandalão, uma mandala comunitária na qual trabalhavam doze famílias, projeto da Agência Mandalla após o estabelecimento da parceria com a Bayer, em 2004. Como na agrovila não há um reservatório d'água, a água que abastecia as mandalas era bombeada do açude, fato que elevou em muito os gastos com energia elétrica. Tais gastos eram rateados por todos os assentados, e aqueles que não possuíam as mandalas nos seus quintais e que viam a conta aumentar sem parar passaram a questionar tal consumo. Além disso, o dinheiro obtido com a comercialização da produção das mandalas não era suficiente para saldar as contas, o que prova sua insustentabilidade, ainda que essa conta não seja feita pelos camponeses. O resultado foi uma dívida acumulada que culminou com o corte do fornecimento da energia elétrica, o que comprometeu o abastecimento d'água inclusive para consumo humano, cujo efeito só foi reduzido diante das implantações das cisternas de placas através do programa $\mathrm{P}_{\mathrm{MC}} \mathrm{M}^{12}$ da ASA, que garantiam a água para consumo humano.

Assim, desde meados de 2005, as mandalas foram paralisadas por falta d'água e, de lá para cá, apesar da conquista do medidor verde (que abate mais de 50\% do valor da conta de energia elétrica) e da negociação para pagamento das contas atrasadas, o problema de falta d'água persistiu e as mandalas deixaram de funcionar. Muitos camponeses inclusive as enterraram (foto 5), para evitar que a água parada das chuvas de verão pudessem colocar em risco a vida das pessoas com a proliferação do mosquito da dengue (foto 6). Do mandalão, atualmente restam apenas as mangueiras (foto 7).

\footnotetext{
${ }^{12}$ Projeto 1 Milhão de Cisternas
} 


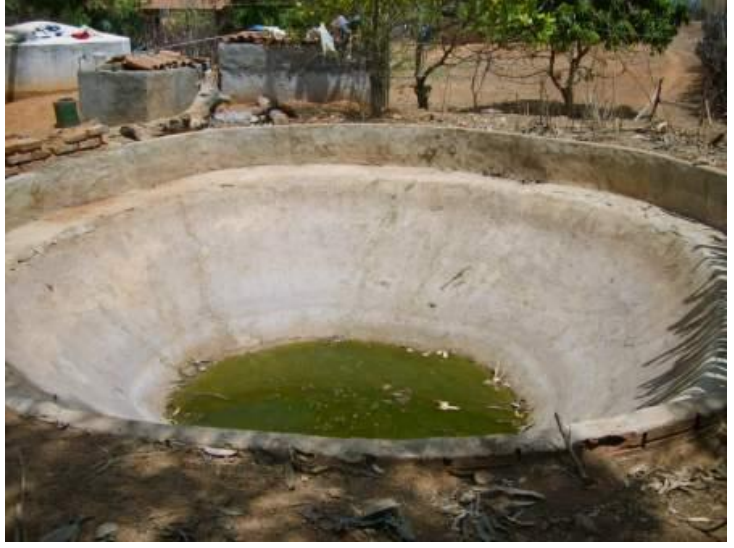

Foto 5 Água parada no fundo de um tanque. Assentamento Acauã, Aparecida-PB. Foto: Roberta T. Oliveira. Fev/2007.

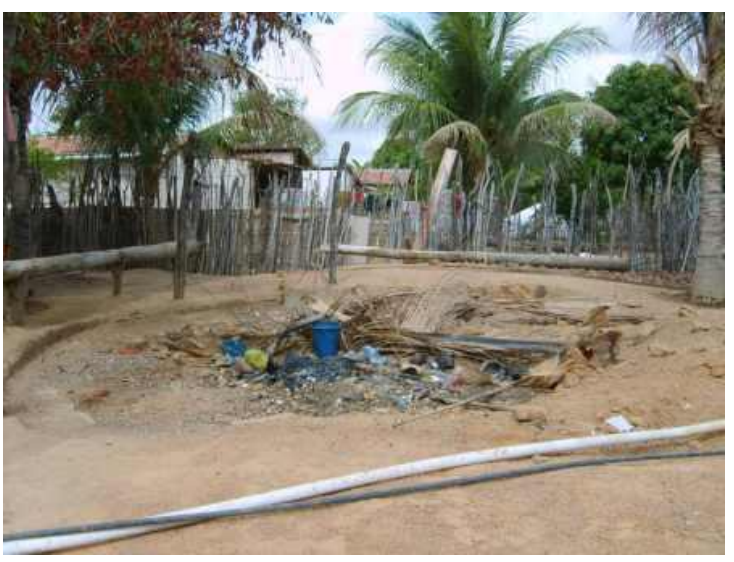

Foto 6 Mandala coberta. Assentamento Acauã, Aparecida-PB. Foto: Roberta T. Oliveira. Fev/2007.

Durante as entrevistas realizadas por ocasião do trabalho de campo, os camponeses eram unânimes em destacar como pontos positivos da mandala a diversificação da produção e dos alimentos na mesa da família, além de uma renda extra obtida com a comercialização, lamentando-se pelo seu encerramento. A idéia germinou e, ainda que não através das mandalas, a produção agroecológica no assentamento Acauã continua sendo uma realidade, porém agora realizada às margens do açude, no baixio (foto 8). Cada família possui uma faixa de terra às margens do açude e algumas delas estão instalando ali suas hortas agroecológicas, com as quais abastecem a mesa de casa e a Feira Agroecológica de Aparecida. O sucesso das hortas cultivadas no baixio serve de estímulo para que cada vez mais famílias vençam as dificuldades impostas pela distância da agrovila e retomem a produção de hortaliças e outras culturas ali, seguindo os princípios da agroecologia. As mandalas não se sustentaram em Acauã, mas a compreensão de que a produção agroecológica é o caminho para a autossustentabilidade germinou. O sucesso da consciência agroecológica pode ser visto na ampliação do número de famílias que aderem à Rede Cultivos Agroecológicos. Acauã é um exemplo, que se multiplica a cada dia entre os camponeses do Alto Sertão paraibano. 


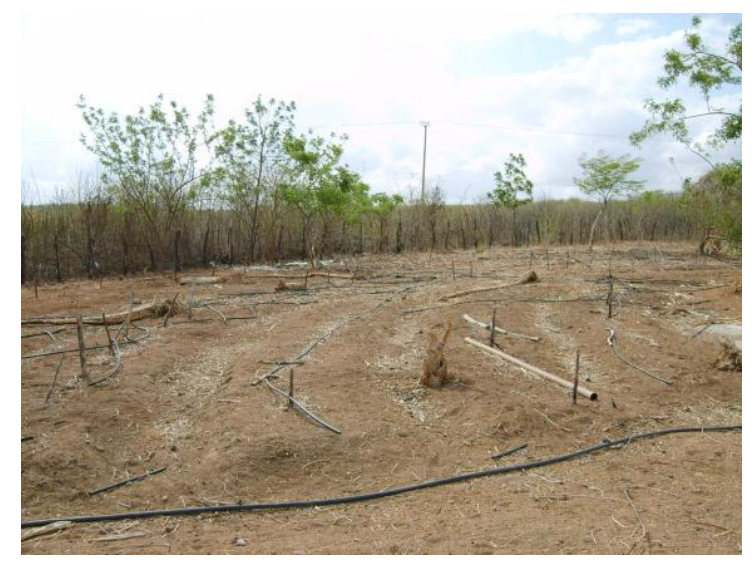

Foto 7 Atual estado do mandalão. Assentamento Acauã, Aparecida-PB. Foto: Roberta T. Oliveira. Fev/2007.

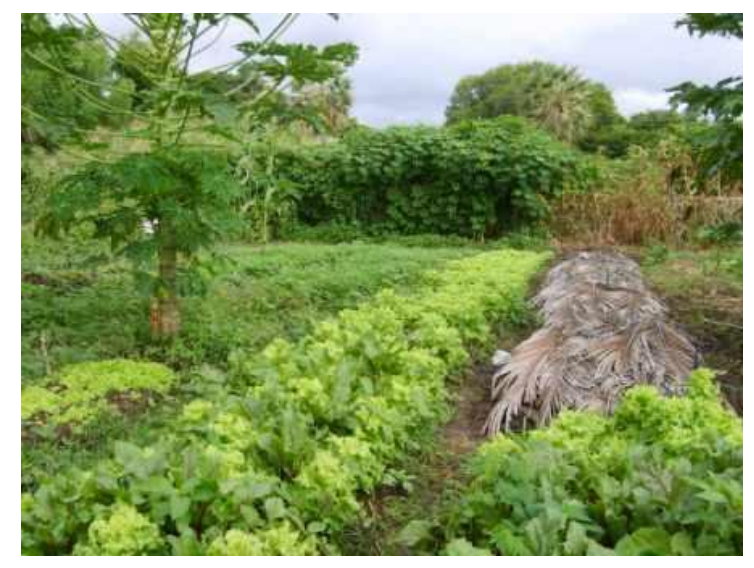

Foto 8 Horta agroecológica às margens do açude (baixio). Assentamento Acauã, Aparecida-PB. Foto: Roberta T. Oliveira. Fev/2007.

\section{FeIra AgroecológicA do CAMPUS I dA UFPB: LIBERDADE E AUTONOMIA NÃO SE GANHAM, SE CONQUISTAM}

Os primeiros passos na direção da construção da Feira Agroecológica do Campus I da UFPB foram dados ainda no final dos anos 1990. A equipe da CPT que acompanhava os assentamentos já havia identificado a dificuldade de comercialização da produção enfrentada pela maior parte dos camponeses assentados, dificuldade esta que foi confirmada através da realização da pesquisa multidisciplinar "Qualidade de vida e reforma agrária na Paraíba”, coordenada por Thomas Bamat e Genaro Ieno Neto, e realizada através da Unitrabalho/UFPB com uma equipe de 12 professores da universidade e 25 estudantes das mais diversas áreas, e da qual também pude participar. A pesquisa, realizada entre 1996 e 1998, abordou questões relativas a educação, saúde, associativismo, participação política, subjetividade, relações de gênero, produção, comercialização e renda em 12 áreas de assentamentos rurais distribuídos no litoral, várzea e agreste paraibanos. Apesar do sucesso alcançado pela maior parte dos assentamentos estudados, relatado inclusive pelos próprios camponeses que, em sua grande maioria, declaravam-se satisfeitos com a vida que levavam, inúmeros foram os problemas identificados a seu tempo no que se referia às condições de produção, comercialização e vida nos assentamentos estudados, problemas os quais, uma vez resolvidos, poderiam melhorar em muito as condições de vida daqueles camponeses. 
No que se referia à comercialização da produção, a pesquisa revelou que a maioria dos camponeses assentados entregava a produção ao atravessador, boa parte deles, inclusive, chegava a vender o produto na folha, ou seja, antes mesmo de realizar a colheita. Os ganhos eram muito baixos, na maioria das vezes insuficientes até mesmo para saldar os débitos de custeio da produção obtidos através do extinto Programa de Crédito Especial para a Reforma Agrária (Procera). Aqueles poucos que tentavam comercializar diretamente com os consumidores enfrentavam uma série de dificuldades, entre elas o alto custo do frete, o alto custo da "pedra" 13 nas feiras e as dificuldades oferecidas pelos atravessadores no Ceasa ${ }^{14}$. Outro problema identificado foi o da pequena diversificação da produção, fato que também contribuía para rebaixar o preço dos produtos no momento da colheita.

Diante da situação relatada com a divulgação dos dados preliminares, a CPT decidiu em 1997 promover uma reunião para começar a discutir os problemas enfrentados pela comercialização e procurar construir, conjuntamente, uma solução viável e eficaz. Inicialmente foram envolvidos todos os assentamentos da várzea paraibana, tendo participado da reunião representantes dos assentamentos, secretários da agricultura e prefeitos dos municípios, representantes do Banco do Nordeste (BNB), da Emater e da universidade. Foram levantadas várias idéias: venda para as escolas, creches e hospitais; venda em caminhões itinerantes, mas as idéias encontravam pouca aceitação. Pensou-se então na possibilidade de criação de uma Central de Abastecimento dos Assentamentos, onde fosse possível a venda direta da produção, idéia que foi rapidamente aceita. Chegou-se a identificar o local, às margens da BR 101 que liga João Pessoa a Recife. Rapidamente, porém, outro problema apareceu: o da baixa quantidade e pouca diversificação dos produtos oferecidos pelos assentamentos, e o resultado foi o abandono da idéia. Levantou-se então a possibilidade de utilização de uma área abandonada próxima ao local da feira realizada em Sapé, para que os camponeses pudessem expor seus produtos, mas a prefeitura não se mobilizou. Pensouse em uma feira em Santa Rita, mas também ali a prefeitura ofereceu uma série de resistências. Enquanto isso os camponeses continuavam vendendo a produção aos

\footnotetext{
${ }^{13}$ Local onde podem expor as mercadorias nas feiras públicas.

14 Segundo os camponeses assentados, os atravessadores no Ceasa organizavam-se em "cartel" e ofereciam um preço ainda mais baixo do que aquele oferecido no assentamento. Muitas vezes os camponeses retornavam com os produtos para o assentamento, tendo ainda que arcar com os custos de transporte e de entrada e saída do Ceasa.
} 
atravessadores e a situação parecia não ter solução. As dificuldades encontradas desestimularam a organização do grupo, e a participação nas reuniões foi diminuindo cada vez mais.

Mesmo com uma participação reduzida, as reuniões continuaram. Foi então que surgiu a consciência, em 1998, da necessidade de buscar o novo, de oferecer produtos diferentes em um mercado igualmente diferente. Diversificar a produção foi o primeiro passo, e foi então que alguns assentados passaram a cultivar hortaliças e a investir em outras culturas, como, por exemplo, a produção de mel. O passo seguinte foi aquele mais importante: a opção por outra produção, a produção agroecológica. Uma representante da Cáritas, que também acompanhava o grupo, viajou para Santa MariaRS para acompanhar de perto as experiências de produção agroecológica ali realizadas, e retornou apresentando a novidade aos camponeses que ainda persistiam em busca de uma solução. O grupo que se interessou pela idéia foi levado para visitar as experiências gaúchas e, diante da constatação de sua viabilidade, optou por dedicar-se àquela forma de cultivo. Foram buscados recursos junto ao BNB e ao Banco do Brasil, mas a resposta foi negativa. O grupo não desistiu e começou, com os poucos recursos existentes, a dedicar-se ao cultivo agroecológico de hortaliças.

Foram necessários alguns anos para que a situação se consolidasse e, muito embora o problema da comercialização da produção não deixasse de ser discutido, ele ainda continuava sem solução. Em 2000, novos passos foram dados. A realização de oficinas sobre a comercialização, abordando aspectos referentes ao relacionamento com o público, preparando os camponeses para o contato com os consumidores, foi uma iniciativa importante. Além disso, incentivou-se a troca de produtos por produtos entre os camponeses, de forma que todos pudessem dispor de uma maior diversificação de alimentos para o consumo sem que para isso tivessem que comprometer boa parte dos poucos recursos obtidos com a comercialização que conseguiam realizar, experiência que foi muito bem aceita por eles. Em 2001, a Cáritas emprestou os R \$ 6.000,00 necessários para o início das atividades. Os técnicos que acompanhavam o grupo realizaram um levantamento da produção e da capacidade produtiva dos camponeses integrantes do grupo, e concluíram que era possível partir para a experiência da comercialização da produção, e o grupo decidiu arriscar. Foram confeccionadas as 
primeiras barracas com o recurso oferecido pela Cáritas e, em novembro de 2001, foi realizada a primeira Feira Agroecológica em uma praça pública próxima ao mercado de Mangabeira, em um dos maiores bairros populares de João Pessoa, tendo sido apurados $\mathrm{R} \$ 600,00$ ao todo.

Foram realizadas mais cinco ou seis feiras em Mangabeira, mas o dinheiro obtido ao final de cada feira era cada vez menor, chegando ao ponto de terem que tirar do bolso para pagar o frete. Diante dessa situação, o grupo decidiu interromper a experiência para avaliar as causas do insucesso. Consciente da viabilidade do projeto, o grupo passou a procurar novas alternativas. Em 2002, conseguiram o apoio da UFPB e assim a feira transferiu-se para o interior do Campus $\mathrm{I}$, inicialmente junto ao estacionamento do Centro de Ciências Humanas, Letras e Artes (CCHLA) e depois no estacionamento próximo à Biblioteca Central, onde funciona até hoje (fotos 9 e 10). De lá para cá tem apresentado um contínuo crescimento (gráfico 1), tanto em número de participantes quanto em número de clientes, prova da aceitação e do sucesso da experiência.

Em 2004 o grupo decidiu criar uma associação para a feira, a "Associação dos Agricultores e Agricultoras Agroecológicos da Várzea Paraibana - EcoVárzea”, que tem por objetivos, entre outros: unir os camponeses que optaram pela agricultura agroecológica, garantindo as condições de continuidade da produção e comercialização da produção dos associados; criar novos canais de escoamento da produção; fortalecer a autogestão dos camponeses e intermediar a elaboração de projetos que visem à melhoria das condições de produção dos associados. 


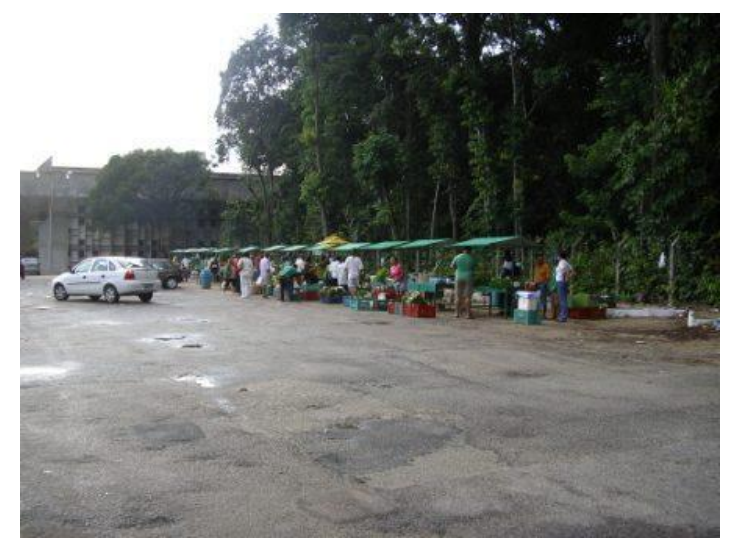

Foto 9 Feira Agroecológica do Campus I da UFPB - Estacionamento Biblioteca Central. Foto: Valeria de Marcos. Ago/2005.

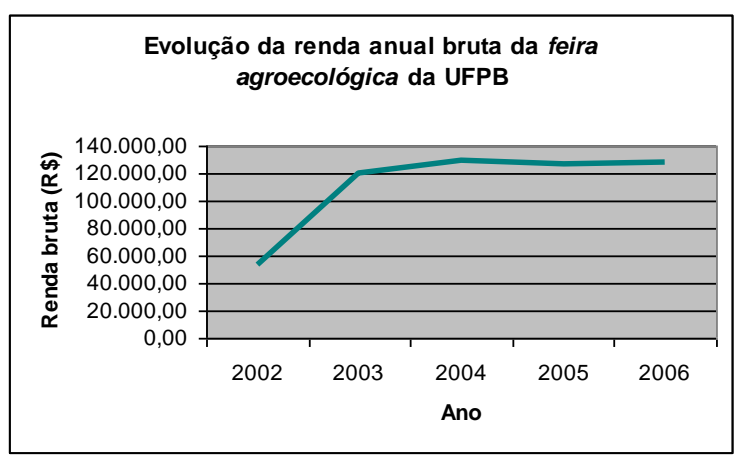

Gráfico 1 Evolução da Renda anual da Feira Agroecológica do Campus I da UFPB. In: SANTOS, T. A., 2007, p. 91.

Atualmente a feira é composta por 20 barracas e mais de 40 camponeses envolvidos diretamente na sua realização, sem contar aqueles que o fazem indiretamente. Participam da experiência grupos de camponeses assentados de quatro áreas de assentamentos rurais: Dona Helena, localizado em Cruz do Espírito Santo, Padre Gino, Rainha dos Anjos e Boa Vista, localizados em Sapé, e o acampamento Ponta de Gramame, localizado no Bairro Valentina, em João Pessoa ${ }^{15}$.

Os camponeses que participam da feira contribuem semanalmente com o "fundo de feira" para cobrir os gastos com a sua manutenção e fazer um caixa que possa ser usado pela feira ou para empréstimo àqueles que precisem, numa clara prova de conquista de autonomia. Atualmente, a contribuição tem sido variada. Aqueles que em tempos anteriores contraíram empréstimos para a realização de melhorias nas condições de produção contribuem com 7\% do apurado na feira. Aqueles que não possuem débitos contribuem com 2\%. A feira está caminhando em direção ao seu oitavo ano de existência, e os resultados são vários: o aumento da independência (em alguns casos, total) com relação ao intermediário; o aumento da renda familiar e a diversificação e aumento da qualidade dos alimentos à mesa das famílias; o aumento da diversificação da produção e a consciência de que é preciso mudar as práticas culturais para melhorar a relação com o ambiente no assentamento e, com ela, a própria qualidade de vida; o

\footnotetext{
15 Ainda que participe da feira, o acampamento Ponta de Gramame não faz parte da Associação EcoVárzea, conforme estatuto elaborado em setembro de 2004 e registrado em cartório em abril de 2005.
} 
aumento da participação dos jovens e mulheres; o fortalecimento dos laços de coletividade e de corresponsabilidade nas decisões da feira, já que a cada fim de feira faz-se uma pequena reunião para resolver eventuais problemas (foto 11), mensalmente ocorre uma reunião da EcoVarzea e anualmente há uma reunião para fazer a avaliação do ano anterior e o planejamento do ano seguinte.

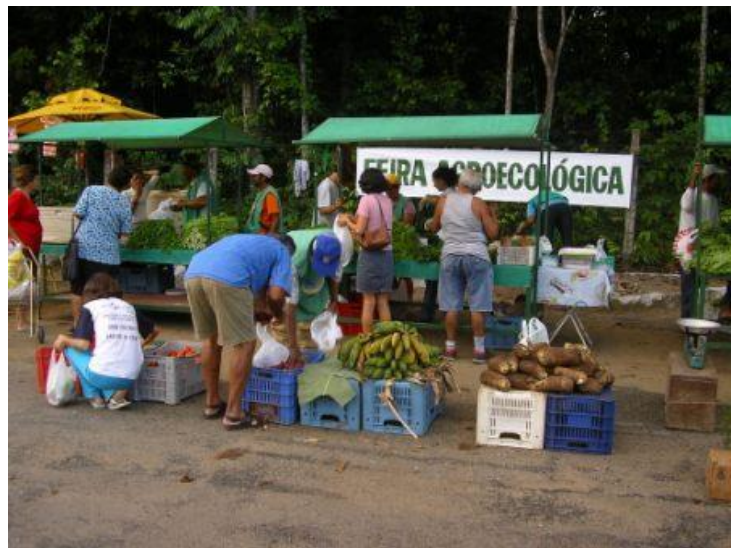

Foto 10 Feira Agroecológica do Campus I da UFPB. Foto: Valeria de Marcos. Ago/2005.

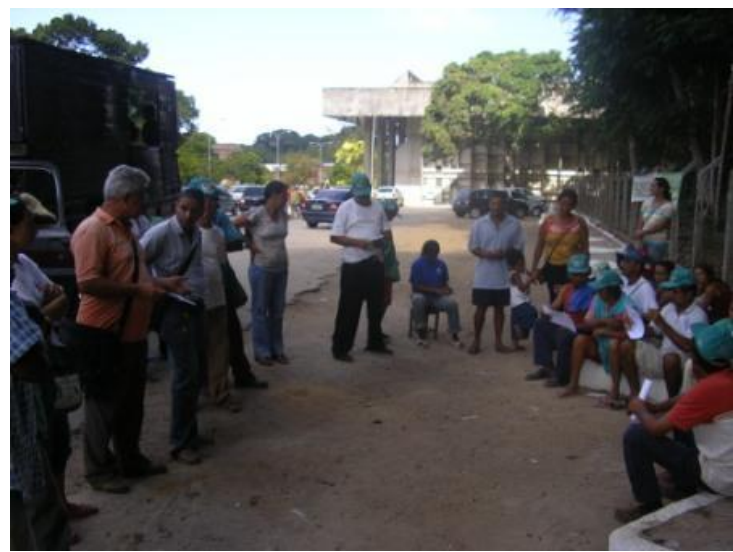

Foto 11 Reunião no final da Feira Agroecológica do Campus I da UFPB. Foto: Valeria de Marcos. Jan/2006.

O que há de novo nessa feira? Difícil é elencar as prioridades:

- A construção coletiva de caminhos para a comercialização, fruto da consciência da impossibilidade de se alcançarem resultados satisfatórios individualmente. Muito embora a apropriação se dê de forma individual, a feira é coletiva, é de todos, como de todos é a responsabilidade pelo seu bom funcionamento;

- A comercialização de produtos da reforma agrária, prova de que, apesar do pouco investimento por parte do governo, ela é já uma realidade;

- A resposta camponesa dada à imposição dos transgênicos, através da prática da agricultura agroecológica, lançando no mercado produtos seguros e soberanos, livres de agrotóxicos e, em boa parte, produzidos através das chamadas sementes crioulas;

- A construção de outro mercado, uma forma de comercialização feita em outras bases: são os camponeses nos ensinando ser chegado o momento de 
diminuir o ritmo e recuperar o tempo, aquele da conversa sinceramente interessada pelo outro, da troca de receitas, do abraço fraterno. Não se trata mais, pois, da relação fria, distante e impessoal entre produtor e consumidor, mas sim de uma relação fraterna, solidária, baseada na confiança e no respeito entre pessoas. Mais do que isso, é a comercialização de produtos ligados ao território e com história, porque produzidos por camponeses com nomes que se fazem chamar na maioria dos casos por apelidos -, desejos, histórias, e sobretudo com um projeto para o Brasil do futuro que, cada vez mais, passa a ser também esse coletivo, enquanto aceito e condiviso pelos seus clientes e amigos;

- A perspectiva de um comércio justo, sem exploração de nenhuma das partes, preço justo para quem produz e quem compra.

Essa experiência é a demonstração clara, como já salientava Marx, de que a resposta da crise está na própria crise, de que não há nada que não possa ser repensado e reconstruído em outras bases. É a prova concreta de que "a classe incômoda" já decidiu o futuro que quer para si, e já começou a construí-lo. É, enfim, a prova de que quem sabe faz a hora, não espera acontecer.

\section{REFERÊNCIAS BIBLIOGRÁFICAS}

ABRAMOVAY, R. De camponeses a agricultores: paradigmas do capitalismo agrário em questão. 354f. Tese (Doutorado em Ciências Sociais) - Depto. de Ciências Sociais, Instituto de Filosofia e Ciências Humanas, Universidade Estadual de Campinas, Campinas, 1990.

ALTIERI, M. e NICHOLLS, C. I. Agroecologia: teoria y pratica para una agricultura sustentable. Mexico: PNUMA, 2000. 250 p. (Edição eletrônica).

CAPORAL, F. R. e COSTABEBER, J. A. Agroecologia: enfoque científico e estratégico. In: http://www.agroeco.org/brasil/material/ConceitoAgroecologia.pdf. Última consulta: 29 jun. 2007.

FABBRICINI, F. e DE FALCO, A. La prima semina. In: “AAM Terra Nuova”, $N^{\circ} 40$ (178). Novembre 2003. p. 70-71. Firenze: AAM Terra Nuova.

FUKUOKA, M. La rivoluzione del filo di paglia: un'introduzione all'agricoltura naturale. Intr. L. KORN. Firenze: Libreria Editrice Fiorentina, 1980. 198 p. (Quaderni D’Ontignano).

La fattoria biologica: teoria e pratica dell'agricoltura naturale. 2a. ed. Roma: Mediterranee, 2001. 315 p. 
HAZELIP, E. Agricoltura sinergica: ecco cos'è. In: "AAM Terra Nuova", $N^{\circ} 34$ (172). Aprile 2003. p. 20-23. Firenze: AAM Terra Nuova.

HOLT-GIMENEZ, E. Campesino a Campesino: A Farmer-led Movement for Sustainable Agriculture in Central America. Policy Report, Food First. 1997

MAGNAGHI, Alberto. Il progetto locale. Torino: Bollati Boringhieri, 2000. 256 p.

MARCOS, V. de. Alternative per la produzione agricola contadina nell'ottica dello sviluppo locale autosostenibile. 2004. 626 p. Tese (Dottorato di Ricerca in Geografia e Pianificazione del Paesaggio per la valorizzazione del patrimonio storico-ambientale) -Dipartimento POLIS, Facoltà di Archittetura dell’Università degli Studi di Genova, Genova, 2004.

Construindo alternativas: a produção agroecológica através das mandalas. In: SIMPÓSIO NACIONAL DE GEOGRAFIA AGRÁRIA, III; SIMPÓSIO INTERNACIONAL DE GEOGRAFIA AGRÁRIA, II; JORNADA ARIOVALDO UMBELINO DE OLIVEIRA. Anais... Presidente Prudente: UNESP, 2005 (CD ROM no prelo).

MOLliSON, B. e HOLMGREN, D. Permacoltura. Intr. Giannozzo Pucci. Fiesole: La Fierucola Editrice, 1992. 143 p.

OLIVEIRA, A. U. de. A agricultura camponesa no Brasil. São Paulo: Contexto, 1991. 164 p. il.

Barbárie e modernidade: as transformações no campo e o agronegócio no Brasil. Revista Terra Livre. São Paulo, a. 19, v. 21, n. 21, p. 113-156. Jul/dez 2003.

Agricultura brasileira: transformações recentes. In: ROSS, J. L. S. (org). Geografia do Brasil. São Paulo: Edusp, 2005. p. 465-534.

OLIVEIRA, A. U. de. Modo capitalista de produção, agricultura e reforma agrária. São Paulo: Labur edições, 2007. 184 p.

OLIVEIRA, M. B. O assentamento Padre Gino-PB e a Feira Agroecológica do Campus I da UFPB. João Pessoa, 2006. 81p.

PORTO GONCALVES, C. W. Geografia da Riqueza, fome e meio ambiente. In: OLIVEIRA, A. U. e MARQUES, M. I. M. O campo no século XXI. São Paulo: Casa Amarela/Paz e Terra, 2004. p. 207-253.

QUAINI, M. La mongolfiera di Humboldt. Dialoghi sulla geografia, ovvero sul piacere di cercare sulla luna la scienza che non c'è. Reggio Emilia: Diabasis, 2002. $354 \mathrm{p}$.

SANTOS, T. A. Território e relações de poder: a busca por autonomia camponesa por meio da feira agroecológica da UFPB. João Pessoa, 2007. 126 p. (monografia)

TAVARES, R. O. A insustentabilidade da mandala no assentamento Acauã, em Aparecida-PB. João Pessoa, 2007. 126 p. (monografia) 